\title{
EFFect OF HeRbicides ON Yield ANd Yield Components OF HybRid MAIZE (Zea mays) ${ }^{1}$
}

\author{
Efeito dos Herbicidas no Rendimento e nos Componentes de Rendimento do Milho Hibrido \\ (Zea mays)
}

\begin{abstract}
KHAN, I.A. ${ }^{2}$, HASSAN, G. ${ }^{2,3}$, MALIK, N. ${ }^{2}$, KHAN, R. ${ }^{2}$, KHAN, H. ${ }^{2}$, and KHAN, S.A. ${ }^{2}$
ABSTRACT - Maize crop (Zea mays) is facing lots of problems from different pests throughout Asia, including Pakistan. Weed infestation is one of the serious pests that remarkably decrease the grain yield in maize. In Khyber Pakhtunkhwa province of Pakistan, the trend of maize hybrid cultivation is gaining the attention of the farmers due to its higher production. Therefore, in this research we tested herbicides (Stomp 330 E, Dual gold 960 EC, 2,4-D, ester) in maize hybrids (P-3025, P-32T78, P-3203). The experiment was done in RCB design with split plots arrangement, where maize hybrids were kept in main plots, while herbicides were assigned to the subplots. Each treatment was repeated three times at the New Developmental Farm (NDF), at the Peshawar University of Agriculture, Pakistan. Results revealed that both hybrids and herbicides significantly increased plant height, biological yield and grain yield. However, the lowest weed density $\left(142.50 \mathrm{~m}^{-2}\right)$ was observed in Dual Gold 960 EC treated plots. Similarly, plant height $(247.188 \mathrm{~cm})$ and grain yield $\left(2.253\right.$ ton $\left.\mathrm{ha}^{-1}\right)$ was maximum in maize hybrid P-3025 and Dual gold treated plots. From the instant experiment, it is concluded that the Dual gold 960 EC herbicide is declared as the best herbicide for weed suppression in maize, while maize hybrid P-3025 was the best hybrid giving maximum yield in the study.
\end{abstract}

Keywords: herbicides, leaf area, maize hybrids, weeds.

RESUMO - A cultura do milho (Zea mays) está enfrentando muitos problemas com diferentes pragas em toda a Ásia, incluindo o Paquistão. A infestação de plantas daninhas é uma das pragas graves que muito diminuiu a produtividade de grãos nessa cultura. Na provincia de Khyber Pakhtunkhwa, no Paquistão, a tendência para o cultivo de milho híbrido está chamando a atenção dos agricultores, devido à sua maior produtividade. Assim, na presente pesquisa foram testados os herbicidas (Stomp diretiva 330 CE, Dual Gold diretiva 960 CE e 2,4-D, éster) em híbridos de milho (P-3025, P-32T78 e P-3203). O experimento foi realizado em delineamento RCB (Randomized Complete Block), por meio de parcelas subdivididas, em que híbridos de milho foram mantidos nos lotes principais, enquanto os herbicidas foram designados em sublotes. Cada tratamento foi repetido três vezes no New Developmental Farm (NDF), da Faculdade de Agricultura de Peshawar, Paquistão. Os resultados revelaram que tanto os hibridos quanto os herbicidas aumentaram significativamente a altura da planta e seu rendimento biológico, assim como a produção de grãos. No entanto, a menor densidade de plantas daninhas $\left(142,50 \mathrm{~m}^{-2}\right)$ foi observada nas parcelas tratadas com Dual Gold 960 CE. Da

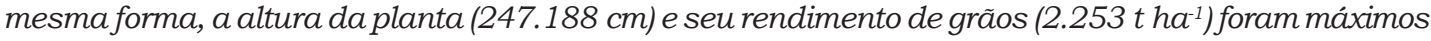
nas parcelas tratadas com milho hibrido P-3025 e Dual Gold. A partir deste experimento, conclui-se que o Dual Gold 960 CE é declarado o melhor herbicida para a supressão de plantas daninhas na cultura de milho, ao passo que o milho híbrido P-3025 foi o melhor híbrido, tendo seu rendimento máximo na área estudada.

Palavras-chave: herbicidas, área foliar, híbridos de milho, plantas daninhas.

Recebido para publicação em 18.10.2015 e aprovado em 27.1.2016.

2 The University of Agriculture, Peshawar-Pakistan; ${ }^{3}$ Shaheed Benazir Bhutto University, Sheringal Dir Upper-Pakistan. <ijazahmadk@aup.edu.pk>. 


\section{INTRODUCTION}

Maize (Zea mays) occupies the key place in the existing cropping system of Pakistan, for it is a short duration crop and provides a more economic return to the growers. In Pakistan, Z. mays is grown on a large area throughout the country. It was cultivated on 1.12 million ha area with a production of 4.22 million tons in the year 2012-2013, showing a $5.4 \%$ increase when compared to the previous year. In the Khyber Pakhtunkhwa (KPK) province in the year 2012-13 the maize crop was grown on an area of 509.1 thousand ha producing an average yield of $1,880 \mathrm{~kg}^{\text {ha }}{ }^{-1}$ (MINFAL, 2013). Due to the introduction of improved hybrid cultivars, the transformation of Pakistan's cotton belt by the substitution of cotton with maize continues, owing to higher economic returns in maize production (MINFAL, 2013).

Worldwide maize is grown as food and fodder crop. It plays an important role in the overall progress of national economy. It is not only the source of food for the increasing population, but also supplies raw material for domestic industry (Hassan, 2000). In spite of its high yield potential, average maize yield in Pakistanis is considered still very low compared to the remaining maize producing countries. Improvement in average yield per hectare can be made if superior genotypes combined with appropriate production technology, i.e. appropriate weed management package is developed and adopted by the growers.

High yielding hybrids and varieties play an important role in high maize production. The Khyber Pakhtunkhwa has an unique agricultural environment, where raising of two maize crops a year are possible, by adopting appropriate cultivars and hybrids. Many hybrids and cultivars classified on the basis of the crop's maturity as early and late maturing are available in the market (Begna et al.,2001). Maize cultivars and hybrids taking a long time to mature may not suit the situation for the field will not be vacated in due course of time to be normally planted with wheat, i.e. disturbing the cropping pattern (Ahmad et al., 2012). Therefore, quick and early maturing hybrids/varieties with high yield are intensely needed. Breeders have developed thousands of maize hybrids, from which one or more can flourish in almost any combination of soil and climate could be found in the farming areas. Hybrids also incorporate favorable qualitative traits to be adapted to diverse environmental conditions, specifically changing the day length (Azam et al., 2007). The yield can be enhanced to a great extent provided that high yielding varieties are identified and planted at suitable times and weeds properly controlled.

Herbicides are truely essential to good yield of maize crop by suppressing different types of weeds. Weeds highly affect maize yield throughout Pakistan competing with crops for light, moisture, space and plant nutrients and thus constantly interfering with the normal growth of crops (Patel et al., 2013). About two hundred and eighty different types of weeds have been recorded in Khyber Pakhtunkhwa with varying infestation status (Marwat, 1984). Herbicides controlled $65-90 \%$ of weed flora and gave $100-150 \%$ more maize yield than weedy check (Nadeem et al., 2006). In Pakistan the chemical weed control is not as popular as in developed countries. Little attention is paid to the herbicide use resulting in an enormous increase of weed population. Taking in consideration the losses due to weeds in maize, a two year repeated experiment was initiated aiming to check different herbicides on the yield of different maize hybrids and explore the phytotoxicity of different herbicides, if any, on maize hybrids.

\section{MATERIAL AND METHODS}

\section{Experimental site and design}

The research entitled "Effect of herbicides on yield and yield components of maize (Zea mays) hybrids" was carried out at the New Developmental Farm (34.0150 North Latitude and $71.5805^{\circ}$ East Longitude), at the University of Agriculture, Peshawar, Pakistan. The experiment was conducted in the summer 2012 and was repeated in 2013 on the same piece of land to confirm previous findings. The experimental design was randomized complete block design (RCB) with split plots arrangement, having three replications. 
Maize hybrids (Pioneer- 3025, Pioneer-32T78, Pioneer 3203) were assigned to main plots, while herbicides (pendimethalin, S-metolachlor, 2,4-D.) were assigned to the subplots.

\section{Crop cultivation}

All the maize hybrids were sown on well prepared seed bed. A recommended basal dose of $60 \mathrm{~kg} \mathrm{ha}{ }^{-1}$ nitrogen and $90 \mathrm{~kg} \mathrm{ha}^{-1}$ phosphorus was applied to the soil before maize sowing and later on the same dose of nitrogen was applied when crop reached knee height. First irrigation was given to the experimental field after two weeks of sowing. Further irrigations were done according to requirements. All other agronomic practices followed uniformly for all the treatments throughout the growing season. The attack of maize stem borer was controlled by Chlorpyrifos 40\% EC @ $1.5 \mathrm{~L} \mathrm{ha}^{-1}$ at 4 weeks after planting. The crop's harvesting was done manually with the help of sickle, while the herbicide application was performed with the help of knap sack sprayer.

\section{Details of treatments}

The details of the treatment are as follows.

\section{Main plot (Maize hybrids)}

1. $\mathrm{H} 1=$ Pioneer -3025

2. $\mathrm{H} 2=$ Pioneer $-32 \mathrm{~T} 78$

3. H3= Pioneer 3203

\section{Subplots (herbicides)}

$\begin{array}{cllll}\text { S. No. } & \text { Treatment } & \text { Common Name } & \text { Time of application } & \text { Rate/kg a.i. ha-1 } \\ \text { 1. } & \text { Stomp 330E } & \text { Pendimethalin } & \text { Pre-emergence } & 0.75 \\ \text { 2. } & \text { Dual gold 960EC } & \text { S-metolachlor } & \text { Pre-emergence } & 1.92 \\ \text { 3. } & \text { 2,4-D 72 (ester) } & \text { 2,4-D } & \text { Post-emergence } & 0.80 \\ \text { 4. } & \text { Weedy check } & - & - & -\end{array}$

\section{PARAMeters STUdied}

During the course of study the following parameters of weeds and maize were examined:.

1. Weed density $\mathrm{m}^{-2}$

2. Fresh weed biomass $\left(\mathrm{g} \mathrm{m}^{-2}\right)$

3. Dry weed biomass $\left(\mathrm{g} \mathrm{m}^{-2}\right)$

4. Plant height $(\mathrm{cm})$

5. Biological yield ton $\mathrm{ha}^{-1}$

6. Grain yield ton ha $^{-1}$

\section{STATISTICAL ANALYSIS}

Each of the parameters recorded for the weed species and the maize during the two years studies were individually analyzed by the Analysis of Variance (ANOVA) through MSTATC computer software (Steel et al., 1997).

\section{RESULTS AND DISCUSSION}

The year effect data were found nonsignificant for all the studied parameters, the pooled data for both the years for each parameter were analyzed.

\section{Weeds density $\left(\mathrm{m}^{-2}\right)$}

Weeds type and severity of weed infestation in field crops are considered the precursor of yield loss in a crop. Therefore, timely control of weeds is very necessary for realizing optimum yield of any crop. In the present study the weed density results $\left(\mathrm{m}^{-2}\right)$ showed significant $(\mathrm{P}<0.05)$ responses for different herbicides and maize hybrids. The average data for maize hybrids indicated that the highest $\left(219.25 \mathrm{~m}^{-2}\right)$ weed density was recorded for P-32T78 and the minimum $\left(148.813 \mathrm{~m}^{-2}\right)$ weed density was noted for hybrid P-3025 (Table 1). Similarly, among the tested herbicides, the lowest $\left(142.50 \mathrm{~m}^{-2}\right)$ weed density was recorded in Dual gold 960EC treated plots, while the maximum $\left(252.25 \mathrm{~m}^{-2}\right)$ weed density was in Weedy check. Likewise, in the case of interaction between maize hybrids and herbicides, the highest $\left(258.75 \mathrm{~m}^{-2}\right)$ weed density was recorded in 
Table 1 - Maize hybrid and herbicides effect on weed density $\left(\mathrm{m}^{-2}\right)$, fresh weed biomass $\left(\mathrm{g} \mathrm{m}^{-2}\right)$, dry weed biomass $\left(\mathrm{g} \mathrm{m}^{-2}\right)$, plant height $(\mathrm{cm})$, leaf area $\left(\mathrm{cm}^{-2}\right)$, biological yield $\left(\right.$ ton ha $\left.{ }^{-1}\right)$ and grain yield (ton ha-1)

\begin{tabular}{|c|c|c|c|c|c|c|}
\hline \multirow[t]{2}{*}{ Factors } & \multirow{2}{*}{$\frac{\text { Weed density }}{\left(\mathrm{m}^{-2}\right)}$} & $\begin{array}{c}\text { Fresh weed } \\
\text { biomass }\end{array}$ & $\begin{array}{c}\text { Dry weed } \\
\text { biomass }\end{array}$ & \multirow{2}{*}{$\frac{\text { Plant height }}{(\mathrm{cm})}$} & $\begin{array}{l}\text { Biological } \\
\text { yield }\end{array}$ & Grain yield \\
\hline & & \multicolumn{2}{|c|}{$\left(\mathrm{g} \mathrm{m}^{-2}\right)$} & & \multicolumn{2}{|c|}{$\left(\right.$ ton ha $\left.^{-1}\right)$} \\
\hline \multicolumn{7}{|l|}{ A) Maize hybrids } \\
\hline Pioneer-3025 & $148.81 \mathrm{~b}$ & $40.94 \mathrm{~b}$ & $9.38 \mathrm{c}$ & $247.18 \mathrm{a}$ & $8.90 \mathrm{a}$ & $2.25 \mathrm{a}$ \\
\hline Pioneer-32 T 78 & $219.25 \mathrm{a}$ & $52.45 \mathrm{a}$ & $14.69 \mathrm{a}$ & $202.00 \mathrm{c}$ & $6.49 \mathrm{c}$ & $1.63 \mathrm{~b}$ \\
\hline Pioneer-3203 & $169.00 \mathrm{~b}$ & $48.12 \mathrm{ab}$ & $11.80 \mathrm{~b}$ & $208.31 \mathrm{~b}$ & $7.82 \mathrm{~b}$ & $2.04 \mathrm{a}$ \\
\hline $\operatorname{LSD}_{(0.05)}$ & 23.34 & 8.383 & 0.666 & 3.432 & 0.526 & 0.350 \\
\hline \multicolumn{7}{|l|}{ B) Herbicides } \\
\hline Stomp330 EC & $155.08 \mathrm{bc}$ & $35.22 \mathrm{~b}$ & $9.55 \mathrm{c}$ & $227.91 \mathrm{~b}$ & $8.479 \mathrm{~b}$ & $2.33 \mathrm{a}$ \\
\hline Dual Gold 960EC & $142.50 \mathrm{c}$ & $31.56 \mathrm{~b}$ & $8.30 \mathrm{~d}$ & $232.66 \mathrm{a}$ & $9.040 \mathrm{a}$ & $2.36 \mathrm{a}$ \\
\hline 2,4-D 72 (ester) & $166.25 \mathrm{~b}$ & $35.92 \mathrm{~b}$ & $10.85 \mathrm{~b}$ & $225.00 \mathrm{~b}$ & $8.029 \mathrm{~b}$ & $1.96 \mathrm{~b}$ \\
\hline No herbicide & $252.25 \mathrm{a}$ & $85.98 \mathrm{a}$ & $19.14 \mathrm{a}$ & $191.08 \mathrm{c}$ & $5.418 \mathrm{c}$ & $1.23 \mathrm{c}$ \\
\hline $\operatorname{LSD}_{(0.05)}$ & 19.58 & 7.992 & 0.8520 & 4.166 & 0.542 & 0.2631 \\
\hline $\begin{array}{l}\text { Interaction } \\
(\mathrm{MH} \times \mathrm{HB}) \mathrm{LSD}_{(0.05)}\end{array}$ & 26.08 & 10.64 & 1.135 & 5.548 & 0.722 & 0.350 \\
\hline
\end{tabular}

Significant at $\mathrm{P} \leq 0.05 . \mathrm{MH}=$ Maize hybrids. $\mathrm{HB}=$ Herbicide.

hybrid P-3203 x weedy check, which is statistically at par with P-32T78 $\mathrm{x}$ weedy check $\left(257.75 \mathrm{~m}^{-2}\right)$. However, the lowest $\left(107.75 \mathrm{~m}^{-2}\right)$ weed density was recorded under the combination of maize hybrid P-3025 and Dual gold 960EC (Figure 1). In similar studies, Khatam et al. (2013) also reported the lowest weed density in herbicides treated plots specifically the Dual gold herbicide for its quick and effective toxicity against maize weeds. The pre-emergent herbicide (Dual gold) is capable to effectively suppress both the seed germination and seedling growth of weeds. Subhan et al. (2007) also found similar results while controlling weeds in maize with different herbicides.

\section{Fresh weed biomass $\left(\mathrm{g} \mathrm{m}^{-2}\right)$}

The results in Table 1 indicated that both the studied factors, i.e., maize hybrids and herbicides significantly affected the fresh weed biomass $\left(\mathrm{g} \mathrm{m}^{-2}\right)$. The maize hybrids average showed that the higher $\left(52.45 \mathrm{~g} \mathrm{~m}^{-2}\right)$ fresh weed biomass was recorded in hybrid P-32T78 and the lower $\left(40.94 \mathrm{~g} \mathrm{~m}^{-2}\right)$ fresh weed biomass was for hybrid P-3025. Among the tested herbicides the maximum $\left(85.98 \mathrm{~g} \mathrm{~m}^{-2}\right)$ fresh weed biomass was recorded in weedy check and the minimum $\left(31.56 \mathrm{~g} \mathrm{~m}^{-2}\right)$ fresh weed biomass was in Dual gold 960EC treated plots. In addition, the fresh weed biomass values found were also significant for the interaction of the maize hybrids and herbicides (Figure 2). The highest $87.56 \mathrm{~g} \mathrm{~m}^{-2}$ weed fresh biomass was found for hybrid P-3203 $\mathrm{x}$ weedy check and the lowest $24.80 \mathrm{~g} \mathrm{~m}^{-2}$ fresh biomass was observed in hybrid P-3025 x Dual Gold 960 EC (Figure 2). The current findings are in line with Adigun \& Lagoke (2003), who found significant reduction in fresh weight of weeds under Stomp and Dual gold herbicides application. Many researchers found that herbicides have great influence on the reduction of the fresh weed biomass (Khan et al., 2009).

\section{Dry weed biomass $\left(\mathrm{g} \mathrm{m}^{-2}\right)$}

The dry weed biomass presents the actual stored dry matter that reflects the capacity of a weed species regarding resources sharing of crop plants. Like the fresh weed biomass of weeds, the dry weed biomass was also significantly affected by the application of different herbicides and maize hybrids. The findings revealed that the maximum $\left(14.69 \mathrm{~g} \mathrm{~m}^{2}\right)$ dry weed biomass was recorded in hybrid P-32T78 and the least $\left(9.38 \mathrm{~g} \mathrm{~m}^{-2}\right)$ dry weed biomass was evaluated for hybrid P-3025. 


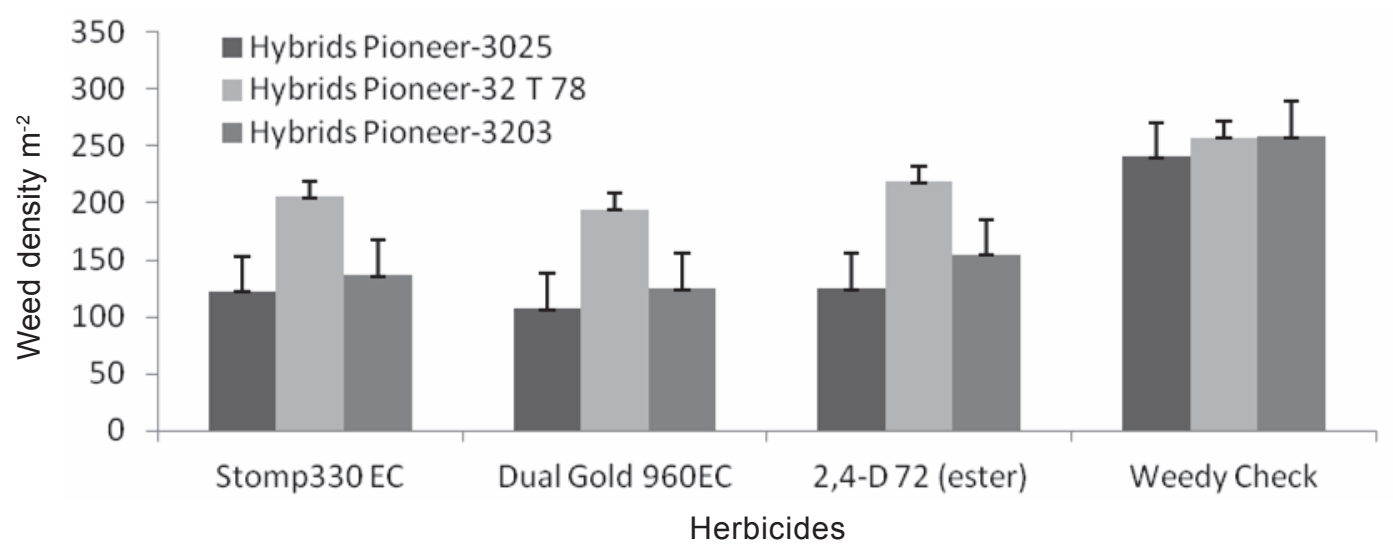

Figure 1 - Interaction of maize hybrids and herbicides on weed density $\mathrm{m}^{-2}$.

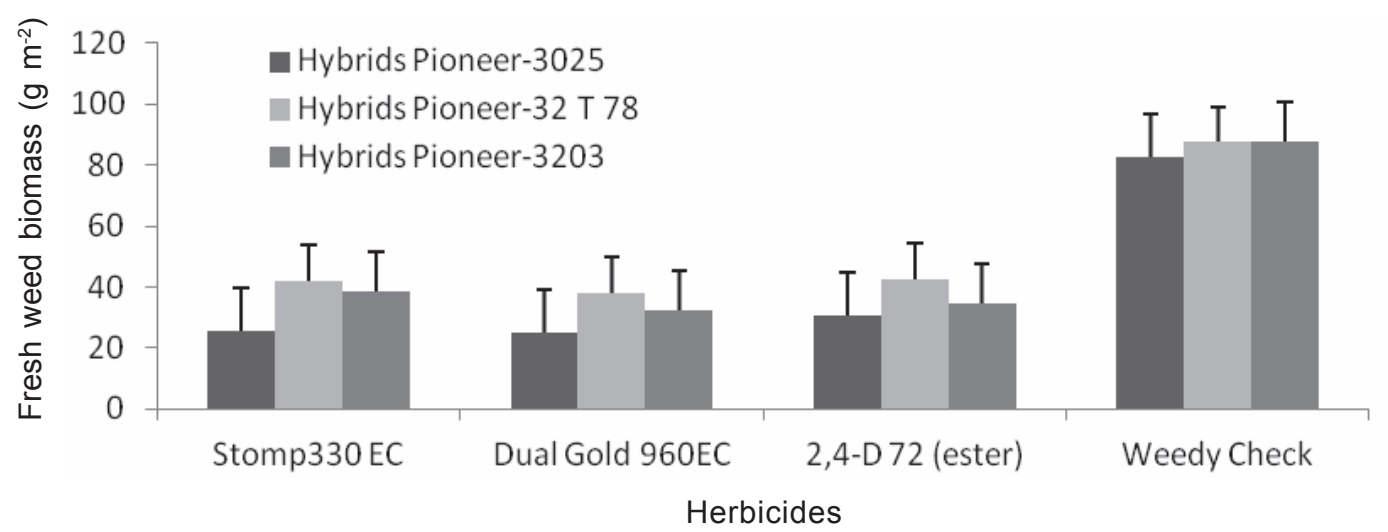

Figure 2 - Interaction of maize hybrids and herbicides on fresh weed biomass $\left(\mathrm{g} \mathrm{m}^{-2}\right)$.

In the case of tested herbicides, the maximum $\left(19.14 \mathrm{~g} \mathrm{~m}^{2}\right)$ dry weed biomass was recorded in weedy check and the minimum $\left(8.30 \mathrm{~g} \mathrm{~m}^{-2}\right)$ dry weed biomass was weighed in Dual gold 960 EC treated plots. Concerning the interaction of maize hybrids and herbicides, the highest $20.02 \mathrm{~g} \mathrm{~m}^{-2}$ weed dry biomass was found for hybrid P-32T78 $\mathrm{x}$ weedy check and the lowest $5.48 \mathrm{~g} \mathrm{~m}^{-2}$ fresh biomass was observed in hybrid P-3025 x Dual gold 960 EC (Figure 3). Our findings are in agreement with the results reported by Waheedullah et al. (2008) and Khan et al. (2012), who also found the lowest dry weed biomass under the application of different pre-emergence herbicides in maize crop.

\section{Plant height $(\mathrm{cm})$}

The results showed significant effects of different herbicides, maize hybrids and their interactions on plant height in maize (Table 1). The data for maize hybrids revealed that the maximum $(247.18 \mathrm{~cm})$ plant height was found for hybrid P-3025, while minimum $(202.00 \mathrm{~cm})$ plant height was noticed in hybrid P-32T78. In herbicides the maximum plant height $(232.66 \mathrm{~cm})$ was recorded in Dual gold 960EC while, the minimum plant height $(191.08 \mathrm{~cm})$ was observed in weedy check. As far as the interaction between herbicides and maize hybrids is concerned, the highest plant height of $270.75 \mathrm{~cm}$ was noted for P-3025 x Dual gold 960EC and the minimum plant height of $186.75 \mathrm{~cm}$ was recorded in P-32T78 $\mathrm{x}$ weedy check (Figure 4). Ahmad et al. (2012) revealed that different maize hybrids showed significant variations for plant height. The reason for these significant differences among various hybrids for various parameters may be due to differences in their genetic background. Subhan et al. (2007) reported 


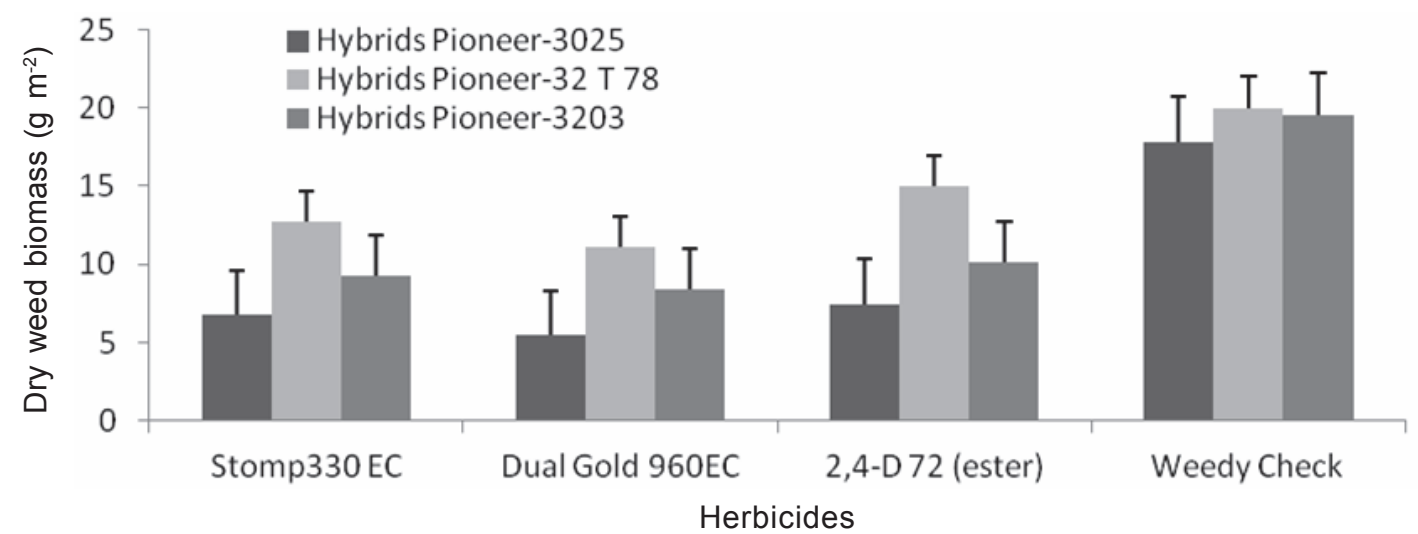

Figure 3 - Interaction of maize hybrids and herbicides on dry weed biomass $\left(\mathrm{g} \mathrm{m}^{-2}\right)$.

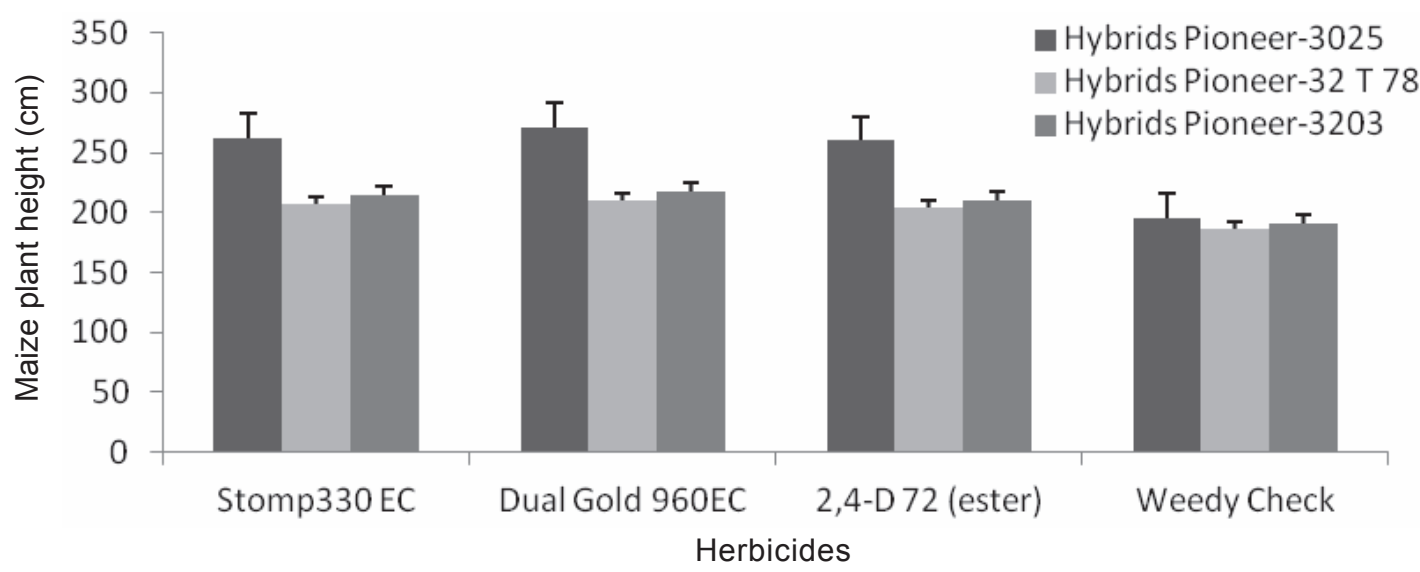

Figure 4 - Interaction of maize hybrids and herbicides on maize plant height $(\mathrm{cm})$.

highest maize plant height, when the crop was treated with Dual gold, Primextra gold and atrazine as pre-emergence. The findings in the present study are similar to Hassan et al. (2010), who reported that herbicides are the most efficient and effective in controlling weeds in $Z$. mays and also increase the plant height, the crop growth and canopy development. These results are also supported by the findings of Stefanovic et al. (2004), who stated that application of herbicides not only suppressed weeds but also enhanced the maize plants height.

\section{Biological yield (ton ha-1)}

In Pakistan farmers also focus on the biological yield along with the grain yield in maize crop due to its bulky and nutritive forage value. Table 1 shows significant results regarding biological yield of maize as affected by different maize hybrids and herbicides application. The maize hybrid $\mathrm{P}-3025$ produced the highest biological yield (8.90 ton ha $\left.\mathrm{h}^{-1}\right)$ and the lowest biological yield (6.49 ton ha-1) was obtained from hybrid P-32T78. Similarly, the herbicide averages demonstrated that Dual gold 960 EC gave the highest (9.04 ton ha-1) biological yield of maize. However, the lowest biological yield (5.418 ton $\mathrm{ha}^{-1}$ ) was obtained from weedy check. The interaction effect showed that the combination of maize hybrid P3025 x Dual gold 960EC gave the maximum biological yield of 11.013 ton ha ${ }^{-1}$, while the minimum biological yield (4.825 ton ha-1) was recorded for maize hybrid P-32T78 x weedy check (Figure 5). The highest biological yield in the herbicides treated plots was due to the appropriate increase in $Z$. mays plant height and attained huge canopy by timely 
application of the herbicides, which decreased the weed species occurrence that ultimately produced robust crop plants. In earlier studies, Chikoye et al. (2010) and Gul et al. (2011) also noticed the same results by achieving higher biological yield due to the effective weed control through different herbicides. Ali et al. (2003) also reported maximum biological yield in herbicide treated plots when compared to weedy check. These findings are also supported by those of Khan et al. (2012), who stated that the use of herbicides for controlling weeds resulted in higher biological yield.

\section{Grain yield (ton ha ${ }^{-1}$ )}

The data analysis showed that grain yield was significantly $(\mathrm{P}<0.05)$ affected by both the examined factors, i.e., maize hybrids and herbicides. For hybrids averages the maximum grain yield (2.25 ton $\mathrm{ha}^{-1}$ ) was recorded in hybrid $\mathrm{P}-3025$ followed by $\mathrm{P}-3203$, while the minimum grain yield (1.63 ton $\mathrm{ha}^{-1}$ ) was seen in plots sown with hybrid P-32T78 (Table 1). In similar studies, Hassan (2000) observed that hybrids significantly differ from each other in terms of yield due to differences in genetic makeup. Among the herbicides, Dual gold 960EC and Stomp 330E treated plots gave maximum grain yield of 2.33 ton ha ${ }^{-1}$ and 2.36 ton ha $^{-1}$ respectively. However, the minimum grain yield of 1.237 ton $\mathrm{ha}^{-1}$ was noted in weedy check. For interaction the maximum grain yield (3.005 ton $\mathrm{ha}^{-1}$ ) was recorded for Dual gold x P-3025, while the minimum (1.037 ton ha-1) grain yield was observed under maize hybrid P-32T78 $\mathrm{x}$ weedy check (Figure 6). In another similar study Nadeem et al. (2006) concluded that the grain yield of maize crop was increased with the use of herbicides as the herbicide application quickly suppresses the weeds germination and

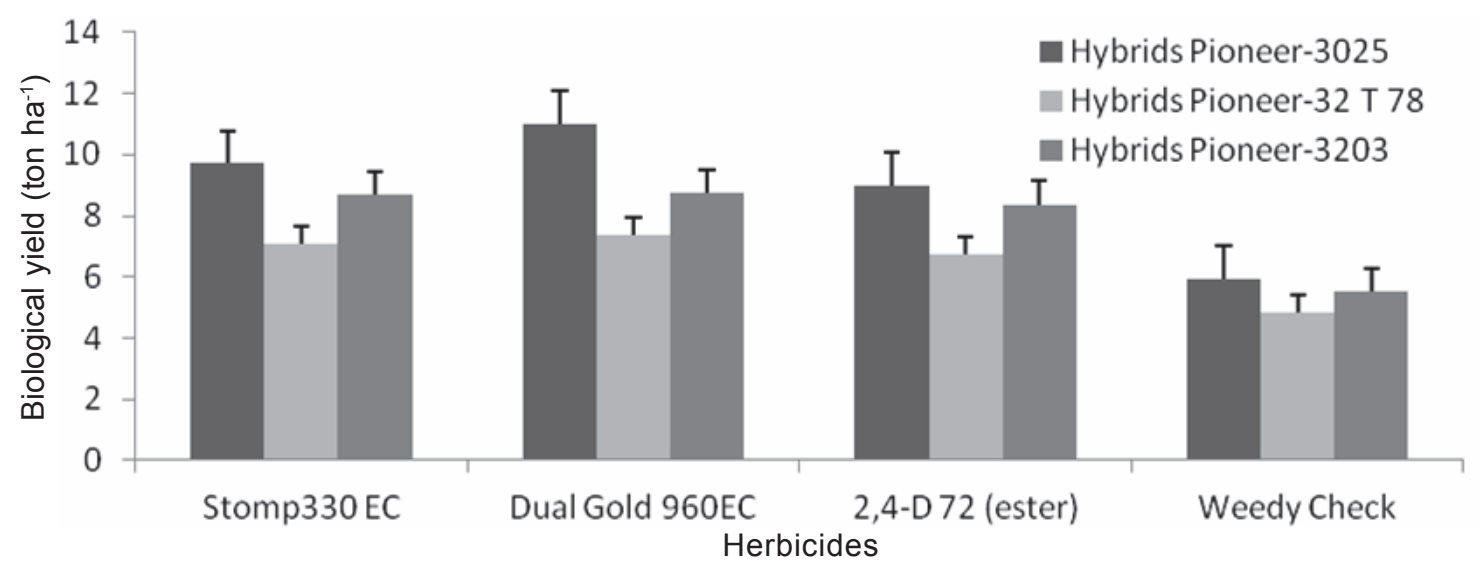

Figure 5 - Interaction of maize hybrids and herbicides on biological yield (ton ha ${ }^{-1}$ ).

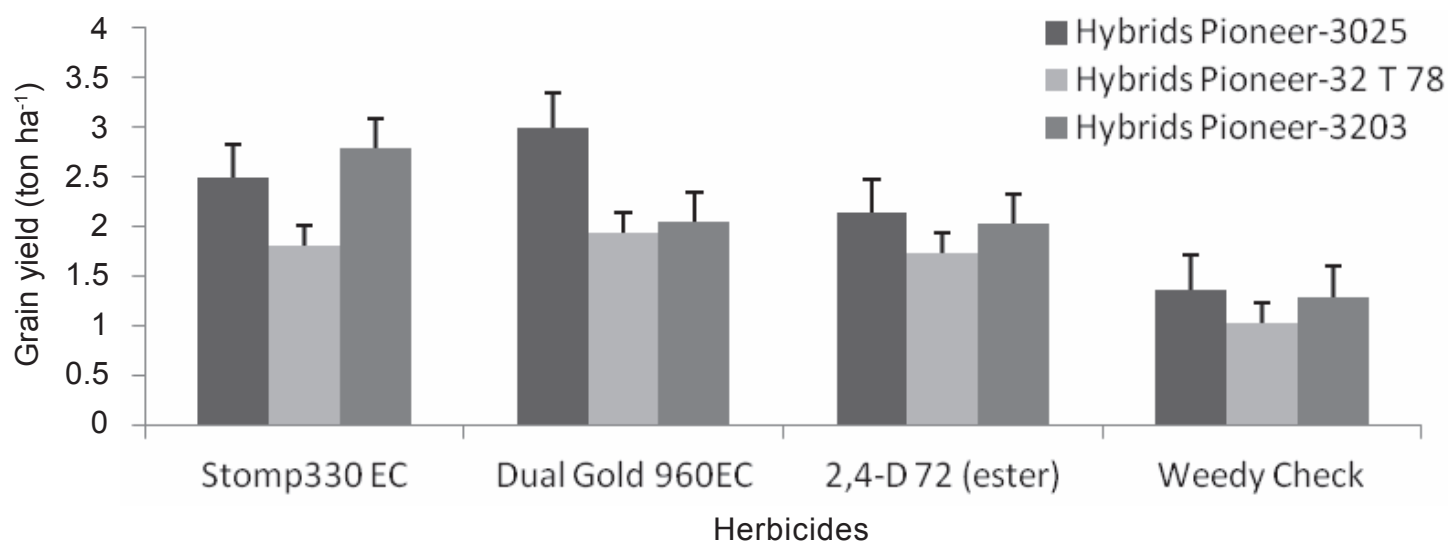

Figure 6 - Interaction of maize hybrids and herbicides on grain yield (ton ha ${ }^{-1}$ ). 
ultimately provides a competition free environment for the crop plant to get all the available resources alone. The results in the present study are similar to the findings of Hassan et al. (2010), who reported that herbicides are the most efficient and effective in controlling weeds in $Z$. mays and also increase the grain yield, crop growth and canopy development. Chikoye et al. (2010) and Khan (2008) also observed remarkable variations in grain yield of $Z$. mays under the application of herbicides with no herbicides.

Conclusion can be drawn from the instant experiments that herbicides play an important role in weed control in maize crop and thus positively affecting yield and yield components of maize. Dual Gold 960 EC proved to be the most suitable herbicide for controlling weeds in different maize hybrids. Moreover, hybrid P-3025 proved to be the best among the other hybrids in terms of producing maximum grain yield. In addition, no phytotoxicity effect was recorded in herbicide-applied plots in the present studies.

\section{LITERATURE CITED}

Adigun J.A., Lagoke S.T.O. Comparison of some pre emergence herbicides mixtures for weed control in maize in the Nigerian Northern Guinea Savanna. J Sustent Agric Environ. 2003;5:63-73.

Ahmad K. et al. Performance of maize hybrids for yield and yield components. Sarhad J Agric. 2004;20:405-8.

Ahmad M. et al. Allometery and productivity of autumn planted maize hybrids under narrow row spacing. Inter J Agric Biol. 2012;12:661-67.

Ali R. et al. Effect of herbicides and row spacingon maize (Zea mays L.). Pakistan J Weed Sci Res. 2003;9:171-8.

Azam S. et al. Effect of plant population on maize hybrids. J Agric Biol Sci. 2007;2:225-30.

Begna S.H. et al. Weed biomass production response to plant spacing and corn (Zea mays) hybrids differing in canopy architecture. Weed Tecnol. 2001;15:647-53.

Chikoye D. et al. Rimsulfuron for post-emergence weed control in corn in humid tropical environments of Nigeria. Weed Technol. 2007;21:977-81.

Gul B. et al. Impact of tillage, plant population and mulches on weed management and grain yield of maize. PakistanJ. Bot. 2011;43:1603-6.

Planta Daninha, Viçosa-MG, v. 34, n. 4, p. 729-736, 2016
Hassan A.A. Effect of plant population density on yield and yield components of 8 Egyptian maize hybrids. B Fac Agric University Cairo. 2000;51:1-16.

Hassan G. et al. Integrating cultivars with reducedherbicides rates for weed management in Z. mays. Pakistan J Bot. 2010;42: 1923-9.

Khan M.I., Hassan G., Khan I. Effect of herbicides doses on fresh and dry weed bio masses of different biotypes of Asphodelustenuifolius L. at various growth stages. Sarhad J Agric. 2009;24:101-5.

Khan M.I. Response of Z $\mathbf{Z}$. mays varieties to different nitrogen levels. Thesis (M.Sc. (Hons) - Department of Agronomy, The University of Agriculture, Peshawar, Pakistan, 2008.

Khan W.K.; Khan N., Khan I.A. Integration of nitrogen fertilizer and herbicides for efficient weed management in Z.mays crop. Sarhad J Agri. 2012;28:457-63.

Khatam A. et al. Effect of various herbicides and manual control on yield, yield components and weeds of maize. Pakistan J Weed Sci Res. 2013;19:209-16.

Marwat K. B. Studies on weeds of important cereal crops of Khyber Pakhtunkhwa (Pakistan). Ph.D Thesis Botany Department University of Peshawar, Pakistan, 1984;95-110.

MINFAL. Agricultural Statistics of Pakistan. Ministry of Food, Agriculture andLivestock (Economic Wing) Islamabad: 2013;18-9.

Nadeem M.A., Tufail M.S., Tahir M. Effect of different herbicides on growth and yield of spring maize (Zea mays L.). In: INTERNATIONAL SYMPOSIUM ON SUSTAINABLE CROP IMPROVEMENT AND INTEGRATED

MANAGEMENT, 2006, Faisalabad. Proceedings...

Faisalabad: University of Agriculture, 2006.

Patel R.H. et al. Weed dynamics as influenced by soil solarization- A review. Agric Rev. 2013;26:295-300.

Steel R.G.D., Torrie J.H., Dickey D.D. Principles and procedures of statistics. 3rd.ed. New York: McGraw-Hill, 1997;178-98.

Stefanovic L. et al. Selectivity of the sulfonylurea herbicide group in the crop of commercial KL maize inbred lines. Herbologia. 2004;5:53-63.

Subhan, F. et al.Response of Z.mays crop to various herbicides. Pakistan J Weed Sci Res. 2007;13:9-15.

Waheedullah, et al. Evaluation of integrated weed management practices for Z.mays. Pakistan J Weed Sci Res. 2008;14:1932. 